\title{
Biochemical and Anatomical Factors Imparting Resistance against Sucking Pests in Cotton
}

\author{
Yallappa Harijan*, G.K. Nishanth, I.S. Katageri, B.M. Khadi and B.R. Patil \\ Department of Genetics and Plant Breeding, University of Agricultural Sciences, \\ Dharwad -580005, India \\ *Corresponding author
}

\begin{abstract}
A B S T R A C T
This experiment was conducted to understand the biochemical and Keywords

Cotton, Gossypol, Reducing sugar, Phenol, Anatomy, RILs.

Article Info

Accepted:

26 June 2017

Available Online:

10 July 2017 anatomical differences in the highly resistant and susceptible recombinant inbred lines (RILs) of cotton for sucking pests. These factors are considered to play a major role in the resistance mechanism against insects. The results in present study was revealed that resistant RILs contain high phenol and gossypol but low in reducing sugar compared to susceptible RILs. Anatomically, resistant RILs had less thickness of leaf lamina, and less distance between lower and upper epidermis of midrib but possessed more number of cortical and palisade cells indicates the compactness of the tissue in leaves and midrib as compared to susceptible RILs. The distance between lower epidermis and phloem was found to be more in resistant RILs compared to susceptible RILs.
\end{abstract}

\section{Introduction}

Cotton is an important fibre crop of global importance and known as the "king of fibre", and in recent times called as "white gold", is the most vital crop of commerce to many countries including India. Cultivated cotton (Gossypium spp.) is the world's leading natural fibre crop and it is the cornerstone of textile industries worldwide. Inspite of several competitions from synthetic fibres, cotton continues to enjoy a place of prime importance in textile industry. In India, cotton provides means of livelihood to millions of farmers and workers and sustains cotton textile industry which annually produces cloth of the value exceeding a thousand crore rupees. Cotton seed had also gained the additional economic importance as a major contributor to edible oil, protein and other by products. The valuable biomass from cotton stalks has become very useful raw material for manufacture of particle boards, paper and other stationaries. In total, cotton has become a highly agro-industrial crop producing $90 \%$ raw material to textile industry and contributes $60 \%$ of oil requirements.

Resistance in varieties offers an inexpensive preventive measure which is generally compatible with other methods of pest control (Choudhary and Arshad, 1989). Defense 
mechanisms in resistant varieties involve either morphological barriers or elaborative array of phytochemicals, which act as repellents, phagodeterrents and oviposition deterrents, and these exhibiting resistances. Polyphenol and phenols are considered to play an important role in plant defense mechanisms. In cotton, phenols and tannins are also found negatively correlated with white fly population densities (Butter et al., 1992).

Anatomical modifications are also known to play a major role in the resistance mechanism against insects. Characters like thickness of leaf, vein toughness, vein turgidity, compactness of tissue in leaf, petiole and stem tip are found to be important against aphid resistance. Thin leaf lamina could be one of the factors imparting resistance against sucking pests. Thinner leaf comprising of higher density of lower epidermal, upper epidermal and mesophyll cells serves the genotypes to have compact leaf lamina. Leaf toughness could limit population buildup of certain pests (Kadapa et al., 1988). In midrib of resistant genotypes compactly arranged cortical cells have less intercellular space for sucking pests (Kadapa et al., 1988). This could favour low piercing rate and also low rate of injection of the phloem and there by imparting resistance to sucking pests. The present study was carried out to understand the role of biochemical components and anatomical differences for sucking pest resistance in cotton recombinant inbred lines.

\section{Materials and Methods}

The experiment was conducted under unprotected condition during Kharif, 2012-13 at Agricultural Research Station, Dharwad Farm, University of Agricultural Sciences Dharwad, which is situated in the northern transitional zone (Zone No. 8) of Karnataka with latitude of $15^{\circ} 26^{1}$ north, longitude of $76^{\circ} 7^{1}$ east and altitude of $678 \mathrm{~m}$ above mean sea level (MSL). Experiment was laid out in black cotton soil and plots were homogeneous with respect to nutrient status.

Out of 190 recombinant inbred lines (RILs) of $\mathrm{F}_{9}$ generation from the cross DS28 $\times$ SBYF425, best 5 resistant and 5 susceptible RILs were selected based on sucking pest (thrips and jassids) and disease reaction (Alternaria, bacterial blight and grey mildew) along with checks were used in this study. Seeds of all RILs were not treated with any fungicides and pesticides to allow the crop to be naturally infected by various diseases and pests in early growth stage. Seeds were hand dibbled in rows of each $6 \mathrm{~m}$ length with spacing of $90 \mathrm{~cm}$ between rows and $20 \mathrm{~cm}$ between the plants. Experiment was done in an augmented design suggested by Federer (1956) with 10 blocks to obtain minimum of 12 error degrees of freedom and five checks viz., DS-28, SBYF 425, Sahana, Suvin and Khanwa-2 repeated in each block. Package of practice recommended for cotton under assured rainfed conditions was followed.

The amount of phenol, gossypol and reducing sugar were estimated from the leaf samples at 120 days after sowing. The procedure used for estimation of different biochemical components is as follows;

\section{Estimation of phenol}

$0.5 \mathrm{~g}$ of the leaf sample was taken and grinded it with pestle and mortar in 10-time volume of $80 \%$ ethanol. Centrifuged the homogenate at $10,000 \mathrm{rpm}$ for 20 minutes, saved the supernatant. Re-extracted the residue with 5 times the volume of $80 \%$ ethanol centrifuged and pooled the supernatants. Then evaporated the supernatant to dryness, after that dissolved the residue in known $(5 \mathrm{ml})$ volume of distilled water. Pipetted different aliquots $(0.2$ 
to $2 \mathrm{ml}$ ) in to test tubes and made the volume in each tube to $3 \mathrm{ml}$ with water. Then, added $0.5 \mathrm{ml}$ of Folin-ciocalteu reagent and $2 \mathrm{ml}$ of $\mathrm{Na}_{2} \mathrm{CO}_{3}$ solution to each tube after 3 minutes. Mixed thoroughly, placed the tubes in boiling water exactly for one minute, cooled and measure the absorbance at $650 \mathrm{~nm}$ against a reagent blank. Prepared standard curve using different concentration of catechol and found the concentration of phenols in the test samples and expressed as $\mu \mathrm{g}$ phenols/ gram material.

\section{Estimation of gossypol}

$5 \mathrm{~g}$ of fresh tissue was taken, cut into small pieces and plunged into boiling $95 \%$ ethyl alcohol (15-20 ml) for 5minutes.Collected the extract by filtering and repeated the extraction with residue and combined the extracts. Diluted the extract with $40 \%$ ethanol and adjusted the extract with $1 \mathrm{~N} \mathrm{HCl}$ to $\mathrm{pH}$ 3.Thenmixed the contents with 1.5 volume of diethyl ether at $10^{\circ} \mathrm{C}$ using a separating funnel and allowed to evaporate the ether extract to dryness and re-dissolved the residue in a known volume of $95 \%$ ethanol. Pipetted different aliquots $(1,2 \mathrm{ml})$ of the gossypol extract in ethanol in test tubes and $0.5 \mathrm{ml}$ of phloroglucinol reagent was added followed by $1 \mathrm{ml}$ of concentrated $\mathrm{HCl}$ to each tubes. Incubated the test tubes for 30 minutes with occasional shaking at room temperature and made the volume of solution to $10 \mathrm{ml}$ with 80 $\%$ ethanol. Measure the absorbance at $550 \mathrm{~nm}$ against a reagent blank and finally prepared a standard graph with gossypol acetate and calculated the concentration of gossypol.

\section{Estimation of reducing sugar}

$100 \mathrm{mg}$ of sample was taken and extracted the sugar with hot $80 \%$ ethanol twice $(5 \mathrm{ml}$ each time). Then collected the supernatant and evaporated by keeping it on a water bath at $80^{\circ} \mathrm{C}$.To dissolve the sugar, $10 \mathrm{ml}$ of water was added and pipetted 0.5 to $3 \mathrm{ml}$ of the extract in test tubes then equalized the volume to $3 \mathrm{ml}$ with water in all tubes. The DNS (dinitrosalicylic acid) reagent $(3 \mathrm{ml})$ was added and these contents were heated in a boiling water bath for 5 minute then $1 \mathrm{ml}$ of $40 \%$ Rochelle salt solution was added when the contents of the tubes were still warm. Samples were cooled and the intensity of dark red color was read at $510 \mathrm{~nm}$. A series of standards were run using glucose (0 to 500 $\mu \mathrm{g})$ and graph was plotted, then calculated the amount of reducing sugars present in the sample using the standard graph.

\section{Procedure for anatomical study}

Fixation, dehydration, paraffin infiltration, embedding and microtoming

The leaves of the same aged plants 5 resistant (DCHRIL 1, DCHRIL 37, DCHRIL 125, DCHRIL 126 and DCHRIL 149) and 5 susceptible (DCHRIL 46, DCHRIL 52, DCHRIL 70, DCHRIL 91 and DCHRIL 164) to pests and diseases were collected separately and fixed in formalin, acetic acid and $70 \%$ alcohol (FAA) in the ratio of $1: 1: 18$. This fixed material was allowed to remain in the solution for 48 hours, then thoroughly washed in $70 \%$ alcohol and further dehydrated by passing through $80 \%$, $90 \%$ and absolute alcohol. The dehydration was carried out with a combination of $\mathrm{n}$ butanol and ethanol (1:3, 1:1 and 3:1 ratio) and also by absolute n-butanol. The material was processed in each of the grades at least for three hours in interval. This dehydrated plant material was kept in specimen tubes containing small quantity of paraffin with a melting point of 58 to $60{ }^{0} \mathrm{C}$ for cold infiltration to get at room temperature for 24 hours. Further, specimen tubes were kept in hot air oven maintained at $60^{\circ} \mathrm{C}$. Subsequently, a change of fresh molten paraffin was added at an interval of four hours 
till a last trace of butanol was removed. The n-butanol free dehydrated material was embedded in paraffin wax by adopting paper boat technique (Jensen, 1962). The paper boats of appropriate size were prepared and inner surface of paper boat was smeared with glycerin. The dehydrated plant material with molten wax was poured into the boats immediately followed by pre-boiled molten wax. For the easy cutting of blocks the material was arranged in proper way in line arrows. The paraffin block containing plant material was cut into proper size (7 micrometer thickness using rotary microtome) and kept under cold water for hardening.

\section{Affixing, deparaffinizing and hydrating the sections}

Gelatin (1\%) was used as an adhesive to fix the sections to slides, which was prepared in warm, distilled water. To this small quantity of potassium dichromate crystals were added and later it was filtered and used to fix the sections to slides. Small amount of gelatin was smeared on the down slides and ribbons of convenient size were spread carefully, these slides were warmed on hot plate maintained at $45^{\circ} \mathrm{C}$ to further stretch the sections. Later the sections were dried at room temperature for 72 hours and stored in a clean slide box. Sections were deparaffinized by using xylene, xylene with alcohol and later hydrated using the alcohol series $(100,90,70$ and $50 \%$ ) and finally with water for 5 minutes in interval.

\section{Staining (Safranin and Fast green method) and Micrometry}

The sections were stained by using a combination of stains (safranin and fast green) for getting anatomical observations and photographs of tissue sections. A stock solution of safranin was made by dissolving $1 \mathrm{~g}$ of safranin in $100 \mathrm{ml}$ of $95 \%$ alcohol. Fast green stain was prepared by adding $0.5 \mathrm{~g}$ of fast green in a mixture of $100 \mathrm{ml}$ of $50 \%$ alcohol and $50 \%$ clove oil. Clove oil mixture was prepared by mixing of $50 \%$ clove oil with $25 \%$ xylene. The sections were deparaffinized (5 minutes) and hydrated as described earlier and stained in safranin for 24 hours. Excess stain was washed in running water and gradually dehydrated by passing rapidly in a series of alcohol like 50, 70, $90 \%$ and absolute alcohol. Counter stained with fast green for a short period of 15 seconds, and then passed in $90 \%$ and absolute alcohol. Excess stain was cleared by clove oil mixture then it was passed with xylene and mounted in DPX. Various anatomical observations were recorded $(10 \mathrm{x})$ and group mean of resistance and susceptible clones were analyzed using ' $t$ ' test. Observation on the number of cells per unit area, thickness of material and size of different tissue of the plant sample were estimated by using calibrated oculometer standardized with help of stage micrometer.

\section{Results and Discussion}

Since, the materials used were the recombinant inbred lines of diverse parents for pests and disease reactions, range of biochemical components and these components play important role in resistance mechanism. The mean of the resistant recombinant inbred lines was $3.40 \mathrm{mg} / \mathrm{g}$ for phenol and $48.78 \mu \mathrm{g} / \mathrm{g}$ for gossypol contents and were more than the mean of susceptible recombinant inbred lines $2.28 \mathrm{mg} / \mathrm{g}$ and 17.78 $\mu \mathrm{g} / \mathrm{gfor}$ phenol and gossypol respectively, in unprotected condition (Table 1 and Fig. 1). Bhaskaran et al., (1925), Van Summere et al., (1975), Rhoades and Cates (1976), Butter et al., (1992) Acharya et al., (2008), and Rohini et al., (2011) reported about the role of phenols and gossypol in resistance mechanism for pests with similar results in cotton. The mean reducing sugar content of 
resistant recombinant inbred lines $(1.55 \mathrm{mg} / \mathrm{g})$ was less than that in susceptible recombinant inbred lines $(2.95 \mathrm{mg} / \mathrm{g})$ in unprotected condition.

Ram Singh and Agarwal (1988); Rana and Manzoor (1990) enlightened the similar kind of results in sucking pest resistance. The results in present study revealed that the resistant RILs had less thickness of leaf lamina, distance between lower and upper epidermis of midrib, but possessed more number of cortical and palisade cells indicating the compactness of the tissue in leaves and midrib compared to susceptible RILs.

The distance between the epidermis and phloem was also significantly more in resistant RILs as compared to susceptible RILs. The compactness of the tissue might have acted as a barrier and prevented the feeding by aphids from leaves.

Thinner leaves in resistant RILs combined with the higher density of upper and lower epidermal cells and mesophyll cells made the lamina of these RILs very compact. In contrast, the susceptible RILs were characterized by thick leaf lamina with loosely arranged epidermal and mesophyll cells, thus making the leaves succulent.

Hence, from the above results, it is possible to postulate that the thin leaf lamina could be one of the factors imparting resistance against sucking pests in resistant RILs studied (Table 2 and Fig. 2). The compact cells could serve as physical barrier for sucking pests due to increased toughness of leaf tissue both for the insersion of the probasis by the sucking pests and also for tissue feeding by other insects (thrips). Several workers on host plant resistance were also of the opinion that leaf toughness could limit population build-up of certain pests (Kadapa et al., 1988; Tikade and Sane, 1962 and Yadav et al., 1967).
The microscopic observations of the midrib and morphological data revealed that the maximum distance between upper and lower epidermis of the midrib in the susceptible RILs was more compared to the resistant RILs. The distance between the lower epidermis and the phloem were also markedly different between the susceptible and resistant RILs. The DCHRIL 125 showed more distance between the lower epidermis and phloem than the susceptible variety. This distance could be termed for our purpose as the "sucking distance".

The thrips and jassids (sucking pests) generally obtain sap from the translocates in the phloem. The sucking distance in association with the number of cells in the cortex tissue could be important in understanding the internal physical environment of the feeding sites of the sucking pests. The average number of cortical cells along the sucking path of the midrib varied significantly among the RILs.

All the resistant RILs had more number of cells per unit area at all the stages compared to susceptible RILs. From this observation, it could be inferred that the cortex of the midrib of the resistant RILs were compactly arranged compared to susceptible RILs. Fewer, loosely arranged cells per unit area provided relatively more inter cellular space in susceptible RILs and this might have helped in easy piercing by the insects. The results obtained are in conformity with those of Kadapa et al., (1962), Yadav et al., (1967) and Kennedy et al., (1978).

Similarly, cuticle is the barrier to insect-pests for piercing into the plant system. The internal hardness of plant tissue such as the region of lignified bundle sheath in leaves and stems could also present obstacles to feeding (Edwards and Wratten, 1982) in case of aphids. 
Table.1 Estimates of biochemical components in recombinant inbred lines

\begin{tabular}{|c|c|c|c|c|c|}
\hline \multirow{2}{*}{ Sl. No. } & \multirow{2}{*}{$\begin{array}{c}\text { Recombinant inbred } \\
\text { lines }\end{array}$} & \multirow{2}{*}{$\begin{array}{l}\text { Reaction for } \\
\text { diseases }\end{array}$} & \multicolumn{3}{|c|}{ Unprotected condition } \\
\hline & & & Reducing sugar (mg/g) & Phenols (mg/g) & Gossypol $(\mu \mathrm{g})$ \\
\hline 1 & DCHRIL 1 & $\mathrm{R}$ & 1.70 & 3.56 & 55.26 \\
\hline 2 & DCHRIL 37 & $\mathrm{R}$ & 1.30 & 3.19 & 50.23 \\
\hline 3 & DCHRIL 125 & $\mathrm{R}$ & 1.62 & 3.25 & 46.51 \\
\hline 4 & DCHRIL 126 & $\mathrm{R}$ & 1.80 & 3.80 & 45.22 \\
\hline \multirow[t]{2}{*}{5} & DCHRIL 149 & $\mathrm{R}$ & 1.35 & 3.20 & 46.68 \\
\hline & & & 1.55 & 3.40 & 48.78 \\
\hline 6 & DCHRIL 47 & $\mathrm{~S}$ & 2.29 & 2.15 & 18.14 \\
\hline 7 & DCHRIL 52 & $\mathrm{~S}$ & 2.79 & 2.55 & 16.56 \\
\hline 8 & DCHRIL 70 & $\mathrm{~S}$ & 3.32 & 2.00 & 16.00 \\
\hline 9 & DCHRIL 91 & $\mathrm{~S}$ & 4.21 & 1.80 & 17.89 \\
\hline \multirow[t]{2}{*}{10} & DCHRIL 164 & $\mathrm{~S}$ & 2.14 & 2.88 & 20.29 \\
\hline & & & 2.95 & 2.28 & 17.78 \\
\hline 11 & DS-28 & $\mathrm{R}$ & 2.25 & 2.60 & 36.28 \\
\hline 12 & SBYF-425 & $\mathrm{S}$ & 3.85 & 2.50 & 30.29 \\
\hline 13 & Sahana & $\mathrm{S}$ & 3.10 & 2.10 & 36.55 \\
\hline 14 & Suvin & $\mathrm{R}$ & 3.80 & 3.21 & 30.10 \\
\hline 15 & Khandwa-2 & $\mathrm{R}$ & 3.85 & 3.10 & 39.19 \\
\hline
\end{tabular}

$\mathrm{R}=$ Resistant

$\mathrm{S}=$ Susceptible 
Table.2 Anatomy of leaf lamina and leaf midrib of RILs

\begin{tabular}{|c|c|c|c|c|c|c|c|}
\hline $\begin{array}{l}\text { Sl. } \\
\text { No. }\end{array}$ & $\begin{array}{c}\text { Recombinant } \\
\text { inbred lines }\end{array}$ & $\begin{array}{c}\text { Reaction to pests } \\
\text { (Jassids and } \\
\text { Thrips) }\end{array}$ & $\begin{array}{l}\text { Thickness } \\
\text { of leaf } \\
\text { lamina } \\
\text { (mm) }\end{array}$ & $\begin{array}{c}\text { Distance } \\
\text { between } \\
\text { upper and } \\
\text { lower } \\
\text { epidermis } \\
\text { (mm) leaf } \\
\text { midrib } \\
\end{array}$ & $\begin{array}{c}\text { Distance } \\
\text { between lower } \\
\text { epidermis and } \\
\text { phloem (mm) } \\
\text { of } \\
\text { leaf midrib }\end{array}$ & $\begin{array}{l}\text { Breadth of } \\
\text { midrib } \\
(\mathrm{mm})\end{array}$ & $\begin{array}{l}\text { No. of cortical } \\
\text { cells/microsco } \\
\text { pic field }(10 x \\
\text { X 10x })\end{array}$ \\
\hline 1 & DCHRIL 1 & Tolerant & 0.199 & 1.510 & 0.560 & 1.370 & 24.084 \\
\hline 2 & DCHRIL 37 & Tolerant & 0.284 & 1.464 & 0.685 & 1.296 & 23.583 \\
\hline 3 & DCHRIL 125 & Resistant & 0.243 & 1.673 & 0.712 & 1.318 & 27.250 \\
\hline 4 & DCHRIL 126 & Resistant & 0.213 & 1.789 & 0.693 & 1.410 & 21.126 \\
\hline 5 & DCHRIL 149 & Tolerant & 0.194 & 1.742 & 0.703 & 1.512 & 19.833 \\
\hline & & & 0.227 & 1.636 & 0.671 & 1.381 & 23.175 \\
\hline 6 & DCHRIL 47 & Highly & 0.321 & 1.810 & 0.618 & 1.609 & 16.333 \\
\hline 7 & DCHRIL 52 & Susceptible & 0.297 & 1.930 & 0.412 & 1.699 & 18.128 \\
\hline 8 & DCHRIL 70 & Susceptible & 0.310 & 2.091 & 0.510 & 1.686 & 17.212 \\
\hline 9 & DCHRIL 91 & Susceptible & 0.318 & 1.963 & 0.550 & 1.708 & 16.167 \\
\hline 10 & DCHRIL 164 & $\begin{array}{c}\text { Highly } \\
\text { susceptible }\end{array}$ & 0.336 & 2.048 & 0.547 & 1.712 & 19.023 \\
\hline & & Susceptible & 0.316 & 1.968 & 0.527 & 1.683 & 17.373 \\
\hline \multicolumn{3}{|c|}{ SEm } & 0.031 & 0.107 & 0.064 & 0.144 & 1.891 \\
\hline \multicolumn{3}{|c|}{$\mathrm{CV}(\%)$} & 15.738 & 8.442 & 15.636 & 13.052 & 14.000 \\
\hline
\end{tabular}


Fig.1 Estimation of biochemical components in recombinants inbred lines

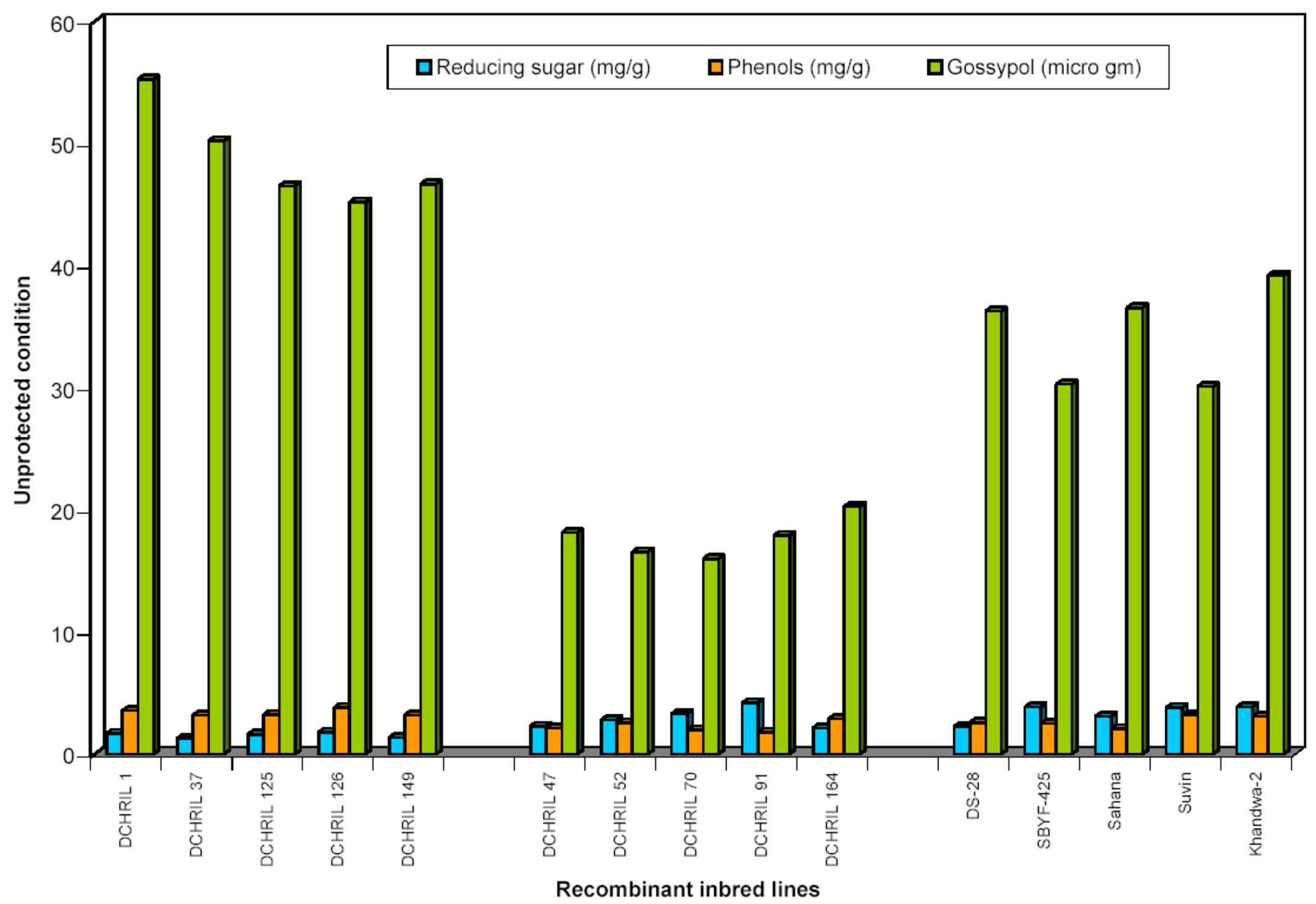


Fig.2 Anatomical differences for leaf lemina in resistant and susceptible RILs

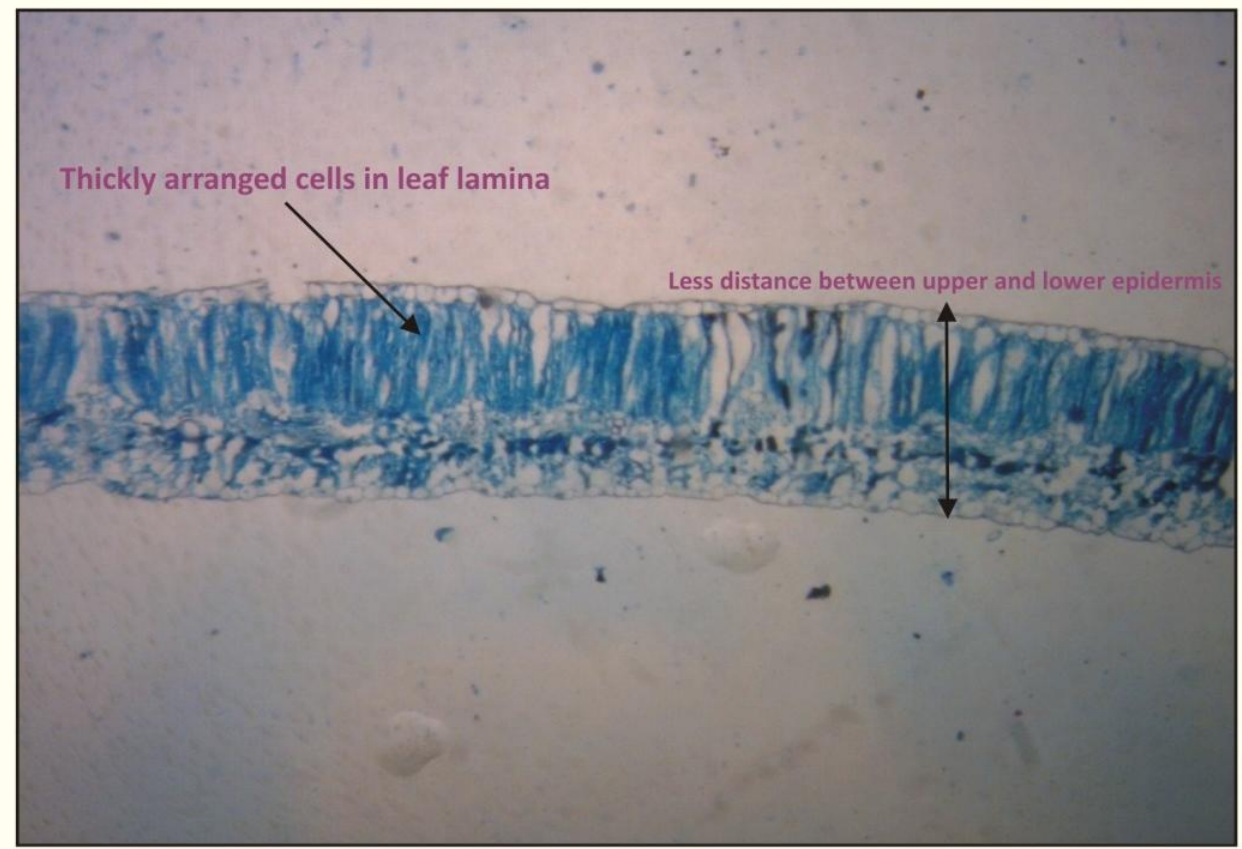

\section{Resistant RIL}

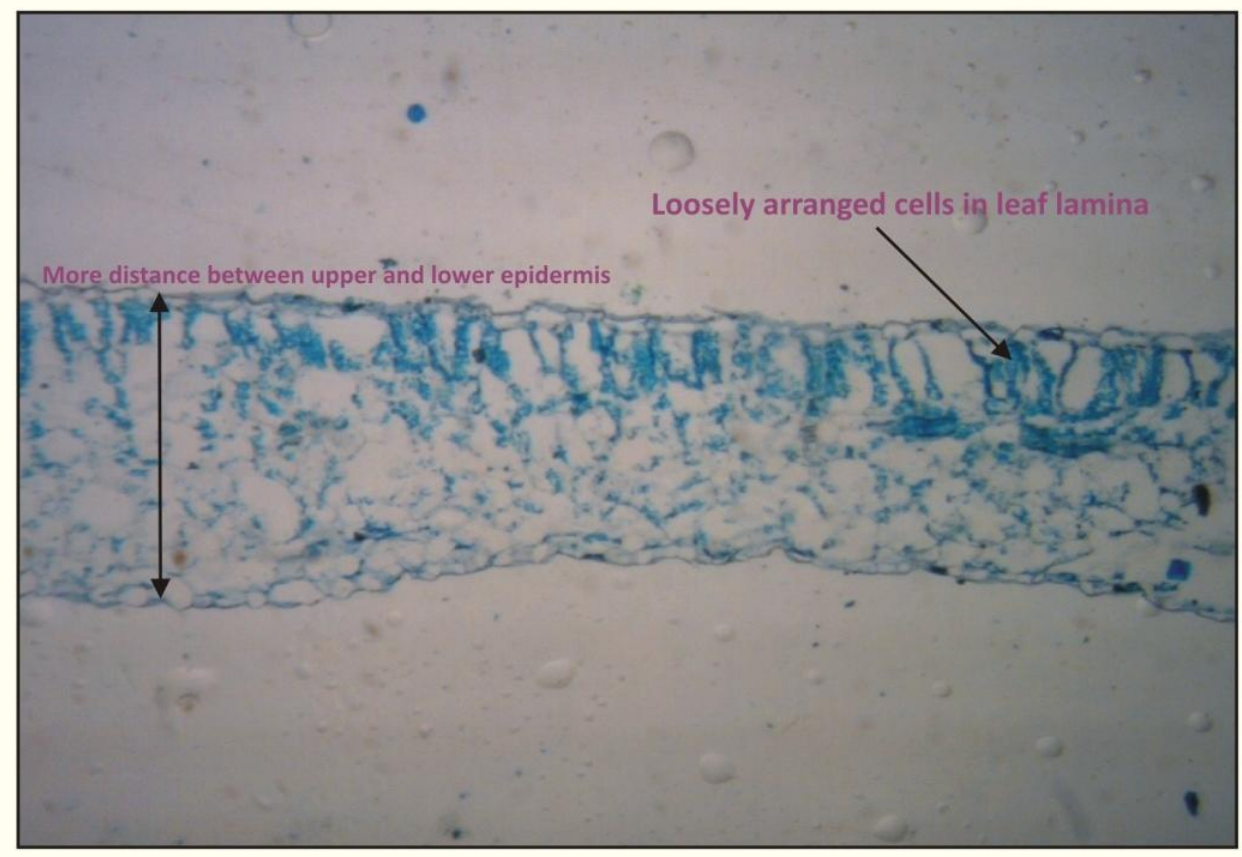

Susceptible RIL 
Fig.3 Anatomical differences for leaf midrib in resistant and susceptible RILs

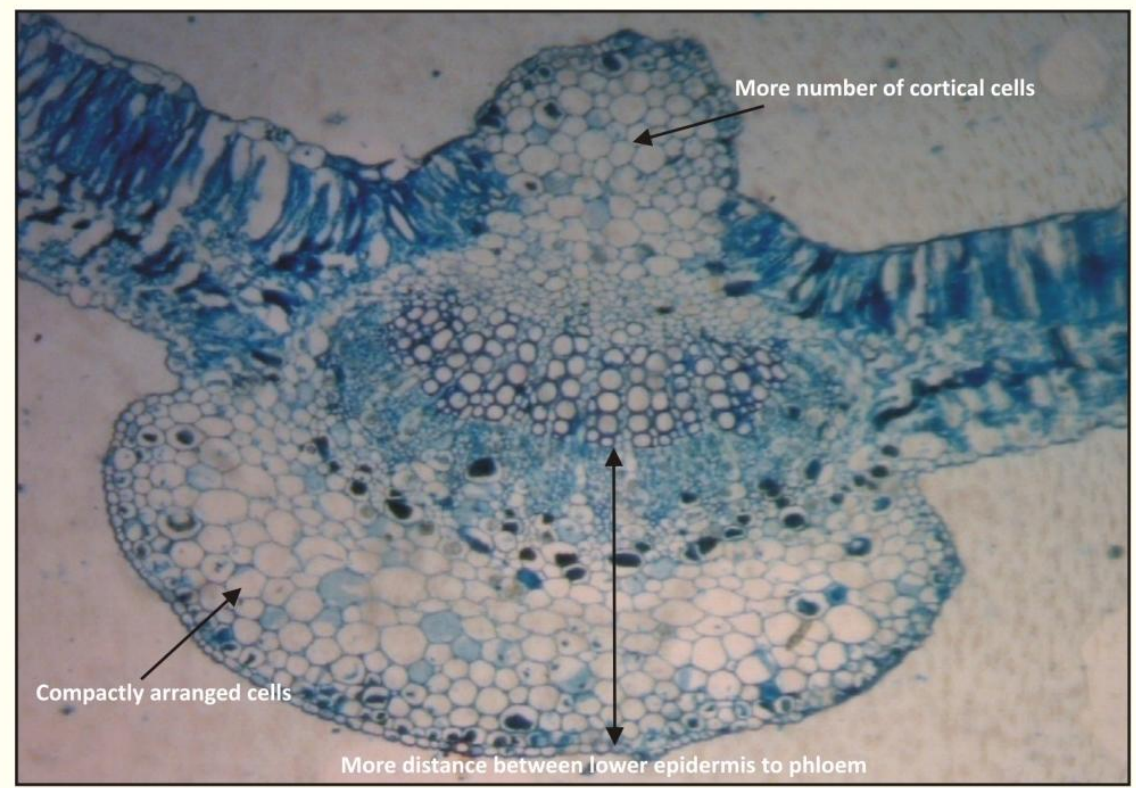

Resistant RIL

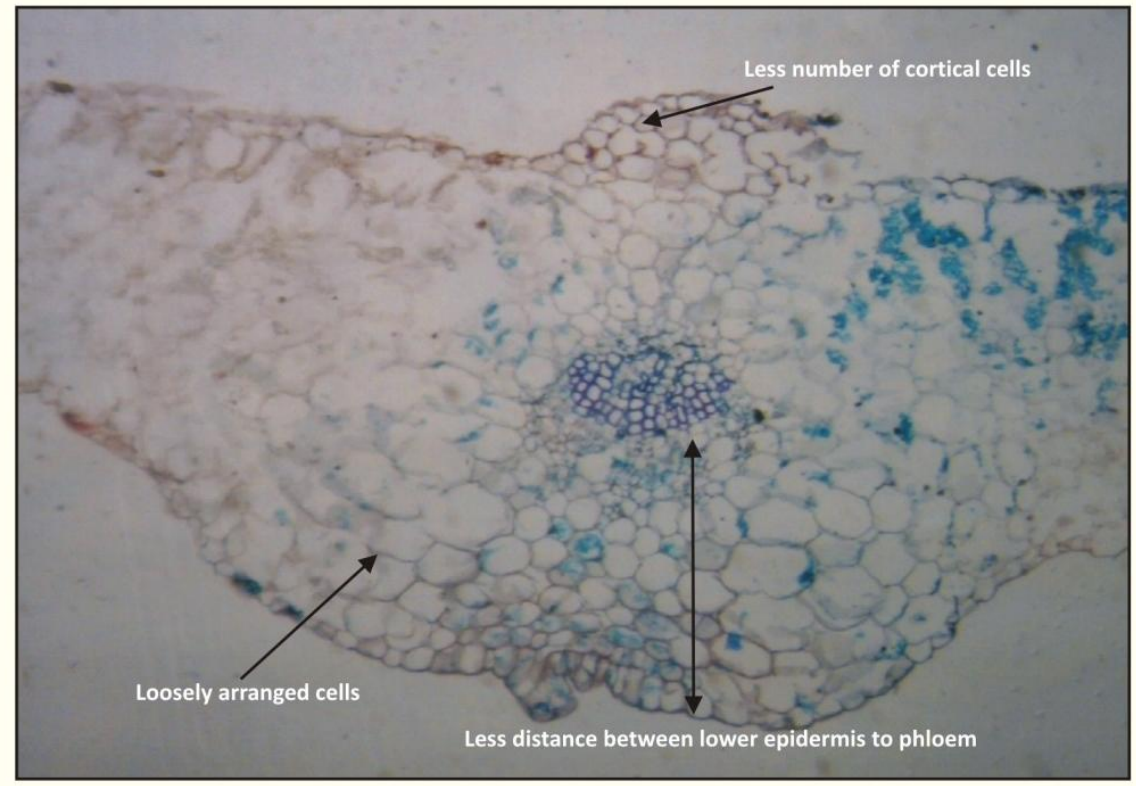

Susceptible RIL

Most aphid species penetrate inter cellularly supported by the action of hydrolytic enzyme in their saliva, particularly pectinase which dissolves the middle lamella between the cells (Klingauf, 1987). Thus, piercing the phloem intercellularly by the aphids in loosely arranged corticale cells in the midrib of susceptible RILs would favour high piercing rate and also high rate of injection of sap from the phloem. The resistant RILs which possessed more densely arranged corticale cells and more distance between epidermis 
and phloem lead to compact area and an increase in the distance for piercing by the proboscis in aphids (Fig. 3). Similar observations like compactness and thin midrib were found to be the factors imparting resistant cotton RILs against jassids (Yadav et al., 1967). It was noticed that the cortex thickness of midrib and nymphal population were more positively correlated (Kennedy et al., 1978). The present study also revealed that the susceptible RILs provide ovipositional sites which are succulent enough for efficient egg laying. But in resistant RILs obstacles were noticed for oviposition by the jassids because of compactness of the tissue and less intra cellular space. Also, the eggs laid on these solid or compact tissues are prone to damage due to desiccation.

In conclusion, the present studies showed, those biochemical and anatomical factors are considered to play a major role in the resistance mechanism against insects. High phenol and gossypol contents in highly resistant recombinant inbred lines impart resistance against sucking pest. Those RILs contain more reducing sugar helps to feed the insects hence susceptible to sucking pests. The compact cells could serve as physical barrier for sucking pests due to increased toughness of the leaf tissue both for the insertion of the probasis by the sucking pests and also for tissue feeding by other insects. The resistant recombinant inbred lines with high per se performance helps to develop the varieties against the sucking pest.

\section{References}

Acharya, V.S. and Singh, A.P. 2008. Biochemical basis of resistance in cotton to whitefly, Bemiciatabaci Genn. J. Cott. Res. Dev., 22(2): 195-199.

Bhaskaran, R. and Muthuswamy, M. 1925. Role of phenolics in verticillium wilts of cotton. Madras Agric. J., 61: 160164.

Butter, N.S., Vir, B.K., Kour, G., Singh, T.H. and Raheja, R.K. 1992. Biochemical basis of resistance to whitefly Bemisiatabaci in cotton. Trop. Agric., 69: 119-122.

Choudhary, M.R. and Arshad, M. 1989. Varietal resistance to cotton insects. Pak. Cottons, 33(1): 44-55.

Edwards, P.J. and Wratten, S.D. 1982. Ecological significance of woundinduced change in plant chemistry. In insect plants.Labeyric, V., fabres, G., Lachaise, D. (Eds). Dr. W. Junk, Publishers, Dodrecht Netherland. Pp. 213-218.

Federer, W.T. 1956. Augmented (or Hoonuiaku) design. Hawaiian Planters Record, 55: 191-208.

Jensen, W.A., Freeman, W. H. and San, Francisco. 1962. Botanical histochemistry: principles and practice pp. vii +408 .

Kadapa, S.N. 1962. A study of $\mathrm{F}_{2}$ generation of inter varietal $G$. hirsutum L. hybrid (H-14 x K-38/14) x (S-41 x Sealand-7) with respect to some economic characters. M. Sc. (Agri.) Thesis, Indian Agric. Res. Institute, New Delhi.

Kadapa, S.N., Vizia, N.C. and Patil, N.B. 1988. A note on stem tip stiffness in aphid tolerant cotton Gossypiumhirsutum L. Curr. Sci., 57: 265-266.

Kennedy, G.G., McClean, D.L. and Kunseym, M. 1978. Probing behaviour of Aphis gossypii on resistant and susceptible musk melon. J. Econ. Ent., 71: 13-16.

Klingauf, F.A. 1987. Host plant finding and acceptance in Aphids: Their biology, natural enemies and control. (Ed) Minks, A.K. and Harrewijn, P., Pub. Eslevier Science Publishing Company, New York. Pp. 197-208.

Ram Singh and Agarwal, R.A. 1988. Role of 
chemical components of resistant and susceptible genotypes of cotton and okra in ovipositional preference of cotton leafhopper. Proc. Animal Sci., 97(6): 545-550.

Rana, M.Y. and Manzoor, A. 1990. Relative resistance of some cotton cultivars against insect pests with reference to physico-chemical characters. Pak. J. Agric. Sci., 27(4): 409.

Rhoades, D.F. and Cates, R.G. 1976. Towards a general theory of plant antiherbivore chemistry. Recent Adv. Phytochem., $10 \mathrm{~J}$ Wallace and $\mathrm{R}$ Mansell (eds). Pp. 168-213.

Rohini, A., Prasad, N.V.V.S.D., Chalam, M. S.V. and Veeraiah, K. 2011. Identification of suitable resistant cotton genotypes against sucking pests. J. Ent. Res., 35(3):197-202.

Tikade, P.M. and Sane. 1962. Jassid resistance and morphological characters of cotton leaf. Indian Cotton Grow. Rew., 16: 324-327.

Van Summere, C.F., Alberencht, J., Deoner, A., Dedoptner, H. and Pe, I. 1975. In: The Chemistry and Biochemistry of Plant Proteins (Edn) Herborne and Vane Sumere, G. F., American Press, Newyork. Pp. 211-264.

Yadav, H.N. and Singh, H.G. 1967. Correlation studies between leaf midrib structure and resistance to jassids, Empoascadevastans Dist. in cotton. Indian J. Agric. Sci., 37: 495-497.

\section{How to cite this article:}

Yallappa Harijan, G.K. Nishanth, I.S. Katageri, B.M. Khadi and Patil, B.R. 2017. Biochemical and Anatomical Factors Imparting Resistance against Sucking Pests in Cotton. Int.J.Curr.Microbiol.App.Sci. 6(7): 2542-2553. doi: https://doi.org/10.20546/ijcmas.2017.607.360 